\title{
Analisis Faktor-Faktor yang Memengaruhi Pertumbuhan Laba LPD di Kota Denpasar Tahun 2014-2017
}

\author{
I Gede Aditya Pratama Putra ${ }^{1}$ \\ I Gusti Ayu Made Asri Dwija Putri \\ ${ }^{1,2}$ Fakultas Ekonomi dan Bisnis Universitas Udayana (Unud), Bali, Indonesia \\ e-mail: adityaputra199626@yahoo.co.id
}

\begin{abstract}
ABSTRAK
Penelitian ini bertujuan untuk mendapatkan bukti empiris dari pengaruh tingkat perputaran kas, tingkat pertumbuhan kredit, tingkat pertumbuhan tabungan, tingkat pertumbuhan biaya tenaga kerja pada pertumbuhan laba. Penelitian ini dilakukan di LPD Kota Denpasar dengan jumlah sampel yang digunakan 34 LPD. Metode penelitain yang digunakan non probalbility sampling yaitu teknik purposive sampling. Teknik analisis yang digunakan adalah teknik analisis linear berganda. Hasil menunjukan tingkat perputaran kas dan tingkat pertumbuhan kredit berpengaruh positif pada pertumbuhan laba LPD di Kota Denpasar tahun 2014-2017, sedangkat tingkat pertumbuhan tabungan dan tingkat biaya tenaga kerja berpengaruh negatif pada pertumbuhan laba LPD di Kota Denpasar tahun 2014-2017

Kata kunci: Perputaran kas, pertumbuhan kredit, pertumbuhan tabungan, pertumbuhan biaya tenaga kerja, pertumbuhan laba
\end{abstract}

\begin{abstract}
This study aims to obtain empirical evidence from the effect of cash turnover rates, credit growth rates, savings growth rates, growth rates on labor costs on profit growth. This research was conducted in Denpasar City LPD with the number of samples used by 34 LPDs. The research method used is non probability sampling, namely purposive sampling technique. The analysis technique used is multiple linear analysis techniques. The results show the cash turnover rate and credit growth rate have a positive effect on LPD profit growth in Denpasar City in 2014-2017, while the savings growth rate and the level of labor costs negatively affect LPD profit growth in Denpasar City in 2014-2017

Keywords: Cash turnover, credit growth, savings growth, labor cost growth, profit growth
\end{abstract}

\section{PENDAHULUAN}

Lembaga Keuangan Bukan Bank (LKBB) adalah lembaga keuangan yang tidak dapat secara langsung menghimpun dana dari masyarakat. LKBB saat ini pada dasarnya meliputi semua lembaga keuangan yang kegiatan pokoknya memberikan jasa-jasa keuangan dan menarik dana dari masyarakat secara tidak langsung. Contohnya: Pegadaian, Asuransi, Koprasi Simpan Pinjam, dan Lembaga keuangan mikro lainnya. 
I Gede Aditya Pratama Putra dan I Gusti Ayu Made Asri Dwija Putri. Analisis ...

Sejak akhir tahun 1990 Lembaga Keuangan Mikro (LKM) telah berkembang sebagai alat pembangunan ekonomi yang bertujuan untuk memberikan manfaat bagi masyarakat berpenghasilan rendah (Rumala Dewi dkk, 2014). Pertumbuhan perekonomian suatau negara memerlukan suatu pengaturan agar lebih terarah sehingga mampu mensejahterakan masyarakatnya dan meningkatkan taraf hidup dari masyarakat itu sendiri (Dhanya Jagadeesh, 2015).

Dalam upaya meningkatkan kesejahteraan masyarakat Desa Pekraman di Bali, maka perlu sebuah Lembaga Keuangan yang menangani perekonomian Desa Pekraman. Oleh karena itu, Gubernur Bali Ida Bagus Mantra pada tahun 1984 memiliki gagasan untuk mendirikan suatu Lembaga Perkreditan Desa (LPD) dengan tujuan menjadikan Lembaga Perkreditan Desa sebagai lembaga yang mampu bersaing dengan sektor perbankan tetapi tetap dengan budaya Bali. Bentuk LPD didasarkan pada warisan budaya berupa desa pakraman yang merupakan suatu bentuk atau wadah sistem pemerintah tingkat desa yang terdiri dari tingkat kekeluargaan (Pemerintah Provinsi Bali, 2002).

Lembaga Perkreditan Desa diperkuat dibawah Payung hukum peraturan daerah (Perda) Provinsi Bali No. 2 Tahun 1988 yang kemudian dirubah dengan Peraturan Daerah Nomor 8 Tahun 2002. Terakhir dengan Peraturan Daerah Nomor 3 Tahun 2017. Pasal 2 ayat 1 Peraturan Daerah (Perda) Provinsi Bali Nomor 3 Tahun 2017 tentang Lembaga Perkreditan Desa mengatakan bahwa, LPD merupakan badan usaha yang pendiriannya dilakukan secara bersama-sama yang melaksanakan kegiatan usaha dilingkungan desa dan untuk Krama Desa. 
LPD merupakan lembaga keuangan yang bersifat khusus yang dilihat dari segi pemupukan modalnya (Suartana, 2009) serta landasan operasional LPD berpegang pada awig-awig desa pakraman, yang mengutamakan hubungan kekeluargaan dan semangat gotong royong antar warga desa pakraman (Cahyadi, 2014). Budaya organisasi yang diterapkan pada LPD yang ada di Provinsi Bali yaitu konsep Tri Hita Karana, yang terdiri dari Parahyangan, Pawongan, dan Palemahan.

LPD dapat berkembang dengan baik apabila semua aspek-aspek pendukung yang ada didalamnya mendapat perhatian yang baik dari manajemen. Termasuk bagaimana proses LPD tersebut dalam memperoleh laba. Walaupun LPD tidak semata-mata berorientasi pada laba namun didalam menjalankan aktivitas usahanya harus memperhatikan bagaimana upaya yang dapat dilakukan agar posisinya tetap menguntungkan sehingga kelangsungan dapat terjaga, Melihat pentingnya LPD yang mampu menunjang perekonomian masyarakat Desa Pakraman, maka kinerja LPD pada saat ini harus lebih mendapatkan perhatian. Laba dapat diperoleh dari pendapatan yang merupakan total manfaat yang dihasilkan oleh semua infrastuktur perusahaan (Bratland, 2010 dalam Pudja \& Suartana, 2014).

Ukuran kinerja sebuah LPD dapat dilihat dari tingkat profitabilitasnya. Profitabilitas menggambarkan kemampuan untuk menghasilkan laba dengan memanfaatkan seluruh aset atau seluruh modal yang dimiliki. Mengungkap potensi laba dalam kemampuan mempredeksi laba telah dilakukan oleh Brown dan Niederhoffer (1968). Tingginya tingkat profitabilitas menggambarkan kinerja 
yang baik dari sebuah LPD, ini membuktikan LPD sudah bekerja secara efektif dan efisien serta memungkinkan untuk memperluas usahanya (Athanasoglou dan Delis, 2008).

Menurut Ketua Pansus Ranperda Revisi Perda LPD I Nyoman Parta (2017) Sampai akhir tahun 2017, Provinsi Bali memiliki 1.443 LPD yang tersebar di Kabupaten atau Kota, yaitu Kabupaten Buleleng. Jembrana, Tabanan, Badung. Gianyar, Bangli, Klungkung, Karangasem, dan Kota Denpasar. Jumlah laba yang diperoleh oleh LPD Provinsi Bali sampai akhir tahun 2017 yaitu termasuk 560 miliar.

Kota Denpasar memiliki 35 LPD dari 4 kecamatan yang ada di Kota Denpasar dengan jumlah laba yang diperoleh LPD Kota Denpasar sampai akhir tahun 2017 yaitu berkisar 73 milyar. Jumlah laba yang diperoleh LPD di Kota Denpasar mengalami pertumbuhan yang pesat. Apabila dilihat dari pertumbuhan labanya, LPD di Kota Denpasar bisa dikatakan mempunyai kinerja keuangan yang cukup baik. Berikut ini merupakan daftar jumlah LPD di masing-masing kecamatan yang berada di Kota Denpasar.

Tabel 1.

Jumlah LPD setiap kecamatan di Kota Denpasar Tahun 2017

\begin{tabular}{ccc}
\hline No & Kecamatan & Jumlah LPD \\
\hline 1 & Denpasar Barat & 2 \\
2 & Denpasar Selatan & 11 \\
3 & Denpasar Timur & 12 \\
4 & Denpasar Utara & 10 \\
& Total & 35 \\
\hline
\end{tabular}

Pendirian LPD di Bali tidak lepas dari masalah-masalah yang muncul, seperti halnya LPD di Kota Denpasar. Di balik pertumbuhan laba LPD di Kota Denpasar yang cukup tinggi, masih saja terjadi penurunan pertumbuhan laba. 
Penurunan tersebut sebagian besar disebabkan olehtata kelola, kinerja keuangan, dan sikap masyarakat dimana LPD tersebut didirikan. Tingkat kesehatan dan keberhasilan suatu LPD salah satunya dapat dilihat dari pertumbuhan labanya.

Profitabilitas (laba) merupakan kemampuan suatu entitas dalam menghasilkan keuntungan serta tingkat efektivitas manajemen suatu perusahaan yang ditunjukkan oleh laba yang dihasilkan dari penjualan dan investasi (Kasmir, 2014:196). Kemampuan suatu entitas dalam mendapatkan laba, menggambarkan tingkat efektifitas pengelolaan perusahaan (Finger, 1994). Efektifitas entitas tergantung pada kemampuan entitas dalam mempertahankan kelangsungan hidupnya, karena profitabilitas menunjukkan bahwa entitas mempunyai prospek yang baik di masa yang akan datang. Semakin tinggi tingkat profitabilitas maka lebih terjamin kelangsungan usahanya, dimana peningkatan profitabilitas setiap tahun suatu LPD dapat dilihat dari pertumbuhan profitabilitas (Seng Sothan, 2014).

Pertumbuhan profitabilitas memberikan wawasan tentang kemampuan perusahaan dalam memperoleh laba pada periode tertentu. Semakin besar profitabilitas berarti semakin baik, karena kemakmuran dan tingkat kesehatan LPD meningkat dengan semakin besarnya profitabilitas. Istilah pertumbuhan profitabilitas dikemukakan oleh Susan, (2006:58), yang didefinisikan sebagai adanya kenaikan atau penurunan yang digunakan untuk mengukur kemampuan suatu perusahaan untuk menghasilkan laba selama periode tertentu dan untuk melihat kemampuan suatu perushaan dalam beroperasi secara efisien. Berikut ini 
merupakan fenomena perkembangan profitabilitas (laba) di masing-masing kecamatan yang berada di Kota Denpasar.

Tabel 2.

Fenomena Perkembangan LPD di Kota Denpasar Tahun 2014-2017

\begin{tabular}{cccc}
\hline No & Kecamatan & Tahun & $\begin{array}{c}\text { Laba/Rugi } \\
\text { (Dalam Ribuan) }\end{array}$ \\
\hline \multirow{2}{*}{1} & Denpasar Barat & 2014 & 5.503 .108 \\
& & 2015 & 6.139 .881 \\
& 2016 & 6.653 .674 \\
2 & 2017 & 7.148 .691 \\
& & 2014 & 11.003 .625 \\
& Denpasar Selatan & 2015 & 28.412 .901 \\
& & 2016 & 30.013 .539 \\
3 & & 2017 & 31.305 .506 \\
& & 2014 & 14.667 .502 \\
& & 2015 & 16.913 .814 \\
4 & & 2016 & 18.931 .616 \\
& & 2017 & 19.745 .114 \\
& & 2014 & 24.492 .787 \\
& & 2015 & 13.529 .612 \\
& & 2016 & 14.618 .696 \\
\end{tabular}

Sumber:Data diolah, 2018

Tabel 2 menunjukkan perkembangan laba di kecamatan yang ada di Kota Denpasar mengalami kenaikan dan penurunan. LPD Kecamatan Denpasar Barat, Denpasar Selatan dan Denpasar Timur selalu mengalami peningkatan laba selama tahun 2014-2017, sedangkan LPD di Kecamatan Denpasar Utara mengalami penurunan laba sebesar $44,76 \%$ ditahun 2015. Fenomena ini menunjukan ada beberapa faktor yang memengaruhi penurunan dan pertumbuhan laba di LPD Kota Denpasar.

Berbagai faktor dan dapat memengaruhi pertumbuhan laba seperti, dikemukakan oleh Sastrawan, dkk. (2014) dalam penelitiannya yang berjudul "Pengaruh Pertumbuhan Tabungan dan Pertumbuhan Kredit Terhadap Profitabilitas pada Lembaga Perkreditan Desa" menunjukkan adanya pengaruh positif dari pertumbuhan tabungan dan kredit secara simultan dan parsial terhadap 
profitabilitas pada LPD Desa Pakraman Banjar tahun 2007-2012. Prawira \& Wisadha (2010) dalam penelitiannya yang berjudul "Pengaruh Tingkat Perputaran Kas, Pertumbuhan Kredit, dan Rasio BOPO Pada Profitabilitas LPD di Kota Denpasar Periode 2006-2010" juga menunjukkan adanya pengaruh secara simultan dan parsial variabel tingkat perputaran kas, pertumbuhan kredit, dan rasio BOPO, sama-sama mempunyai pengaruh signifikan pada profitabilitas LPD di Kota Denpasar periode 2006-2010.

Berbeda dengan penelitian yang dilakukan oleh (Arta \& Kesuma, 2012) yang berjudul "Pengaruh Tingkat Perputaran Kas, Tingkat suku Bunga Kredit, dan Pertumbuhan Kredit Terhadap Profitabilitas Lembaga Perkreditan Desa di Kecamatan Tegallalang, Gianyar menunjukan variabel tingkat perputaran kas memiliki pengaruh yang negatif dan signifikan terhadap profitabilitas dan variabel pertumbuhan kredit memiliki pengaruh negatif dan tidak signifikan terhadap profitabilitas. LPD di Kecamatan Tegalalang, Gianyar. Cahyani dan Dana (2014), variabel bebas tingkat pertumbuhan tabungan secara parsial berpengaruh negatif dan tidak signifikan terhadap profitabilitas Lembaga Perkreditan Desa Kabupaten Badung periode 2010-2012.

Perputaran kas merupakan periode berputarnya kas yang dimulai pada saat kas dinvestasikan dalam komponen modal kerja sampai saat kembali menjadi kaskas sebagai unsur modal kerja yang paling tinggi likuiditasnya (Menuh, 2008). Secara sederhana dapat dikatakan bahwa tingkat perputaran kas adalah kemampuan suatu perusahaan menggunakan kasnya secara efisien. Semakin tinggi efisiensi penggunaan kasnya, menunjukkan tingkat perputaran kas yang 
tinggi, sehingga dapat meningkatkan partumbuhan laba perusahaan (Abdurrahman dan Nasri, 2015).

Penelitian yang dilakukan oleh Sutika \& Sujana (2013), menemukan bahwa apabila tingkat perputaran kas meningkat, maka profitabilitas LPD di Kecamatan Ubud juga akan meningkat. Hal ini berarti bahwa apabila tingkat perputaran kas semakin tinggi maka semakin tinggi efisiensi dan efektif penggunaan kas, yang akan berdampak pada meningkatnya profitabilitas LPD. Menurut Pratama \& Putri (2013), besar kecilnya kas dan tinggi rendahnya tingkat perputaran kas memperlihatkan efisiensi penggunaan kas pada perusahaan. Semakin banyak uang kas yang ada di perusahaan berarti semakin banyak kas yang kurang efektif dan ini bisa berdampak pada profitabilitas. Semakin tinggi tingkat perputaran kasnya berarti semakin besar kesempatan BPR untuk menghasilkan laba.

Penelitian lain yang juga sejalan dengan pernyataan tersebut yaitu penelitian yang dilakukan oleh Prawira \& Wisadha (2010), Tingkat perputaran kas berpengaruh signifikan pada profitabilitas LPD di Kota Denpasar yang berarti jika tingkat perputaran kas meningkat maka profitabilitas juga akan meningkat, karena dengan tingkat perputaran kas yang tinggi telah menunjukkan bahwa terjadinya volume transaksi yang tinggi, dengan tingkat pendapatan yang lebih besar akan memberikan kemungkinan laba yang lebih besar sepanjang biaya operasional tidak meningkat. Peningkatan laba yang diterima akan membuat tingkat profitabilitas menjadi meningkat. Berdasarkan uraian tersebut. maka dapat dibuat hipotesis sebagai berikut: 
$\mathrm{H}_{1}$ : Tingkat perputaran kas berpengaruh positif terhadap pertumbuhan laba LPD.

Kredit merupakan suatu fasilitas keuangan yang memungkinkan seseorang atau badan usaha untuk meminjam uang untuk membeli produk dan membayarnya kembali dalam jangka waktu yang ditentukan (Idowu dan Awoyemi 2014). Salah satu fungsi LPD yaitu menyalurkan kredit kepada masyarakat Desa Pakraman. Penyaluran kas dalam bentuk kredit kepada masyarakat akan meningkatkan pertumbuhan laba. Salah satu fungsi LPD yaitu menyalurkan kredit kepada masyarakat Desa Pakraman. Penyaluran kas dalam bentuk kredit kepada masyarakat akan meningkatkan pertumbuhan laba. Jika penyaluran dan perputaran kredit dilakukan dengan baik, maka akan meningkatkan pertumbuhan laba LPD yang tinggi (Dewi \& Budiartha, 2017). Dengan kata lain, kredit yang diberikan oleh LPD merupakan salah satu pemasukan bagi LPD. Tetapi apabila kredit yang disalurkan oleh LPD sebagian besar mengalami kredit macet, maka hal tersebut akan berdampak terhadap kesehatan LPD.

Berdasarkan penelitian yang dilakukan oleh Sastrawan, dkk. (2014) menyatakan bahwa pertumbuhan kredit berpengaruh positif dan signifikan terhadap pertumbuhan profitabilitas pada Lembaga Perkreditan Desa (LPD) Desa Pakraman Banjar. Hal ini mengindikasikan bahwa semakin besar tingkat pertumbuhan kredit yang disalurkan oleh LPD Desa Pakraman Banjar, maka profitabilitas juga akan mengalami pertumbuhan.

Hal tersebut sejalan dengan hasil penelitian yang dilakukan oleh Prawira \& Wisadha (2010), Pertumbuhan kredit berpengaruh signifikan pada profitabilitas LPD di Kota Denpasar periode 2006-2010 yang berarti jika pertumbuhan kredit 
meningkat maka profitabilitas juga akan meningkat, hal ini disebabkan karena manajemen LPD berhasil menyalurkan sebagian besar dana simpanan nasabah ke dalam bentuk pinjaman kepada nasabah yang membutuhkan kredit, semakin banyak kredit yang di salurkan kepada masyarakat maka semakin banyak pendapatan bunga yang diterima LPD sehingga profitabilitas LPD juga akan semakin meningkat. Berdasarkan uraian tersebut, maka dapat dibuat hipotesis sebagai berikut:

$\mathrm{H}_{2}$ : Tingkat pertumbuhan kredit berpengaruh positif terhadap pertumbuhan laba LPD.

Pertumbuhan tabungan menunjukkan perkembangan jumlah tabungan periode sekarang dibandingkan dengan jumlah tabungan periode sebelumnya. Secara umum, saat LPD menerima tabungan dari para nasabah dan terus mengalami pertumbuhan dengan catatan para pengelola LPD mampu untuk menyalurkan kembali dana tersebut dalam bentuk kredit atau menginvestasikannya dengan baik, secara otomatis laba yang akan diterima tersebut juga akan ikut tumbuh karena dengan investasi atau menyalurkan dana LPD tersebut kembali dalam bentuk kredit, LPD dapat menutupi biaya operasional yang dikeluarkan untuk membayar bunga tabungan nasabah.

Sesuai dengan penelitian yang dilakukan Mukarromah \& Badjra (2015), menyatakan pertumbuhan tabungan berpengaruh positif dan signifikan terhadap pertumbuhan profitabilitas. Keadaan tersebut dapat disebabkan oleh terjadinya ketidak seimbangan dana yang dihimpun dengan dana yang disalurkan oleh BPR.

Penelitian lain yang juga sejalan dengan pernyataan tersebut yaitu penelitian yang dilakukan oleh oleh Dewi \& Suartana (2017), menyatakan hasil 
analisis data dengan menggunakan metode analisis regresi linear berganda menunjukkan bahwa tingkat pertumbuhan tabungansecara parsial berpengaruh positif dan signifikan pada pertumbuhan laba LPD. Hal ini disebabkan karena, saat LPD menerima tabungan dari para nasabah dan terus mengalami pertumbuhan maka manajemen keuangan LPD harus mampu mengelola kas yang masuk dari tabungan tersebut agar tidak ada kas menumpuk. Berdasarkan uraian tersebut, maka dapat dibuat hipotesis sebagai berikut:

$\mathrm{H}_{3}$ : Tingkat pertumbuhan tabungan berpengaruh positif terhadap pertumbuhan laba LPD.

Pertumbuhan biaya tenaga kerja dapat dilihat dari pertumbuhan biaya tenaga kerja yang dibayarkan oleh LPD pada periode sebelumnya dibandingkan dengan biaya tenaga kerja yang harus dibayarkan pada periode sekarang. Biaya tenaga kerja merupakan salah satu biaya operasional yang dikeluarkan oleh LPD. Laba atau rugi dari suatu LPD didapatkan dari hasil pengurangan antara pendapatan operasional LPD dengan biaya operasional LPD. Semakin besar jumlah biaya tenaga kerja yang dibayarkan dapat menambah jumlah biaya operasional LPD, sehingga laba yang diperoleh oleh LPD akan semakin menurun.

Berdasarkan penelitian yang dilakukan oleh Martha, dkk (2015) dan Oki (2010), yang menunjukkan bahwa biaya operasional memiliki pengaruh yang negatif terhadap laba. Artinya, semakin tinggi nilai biaya operasional maka semakin rendah laba yang diperoleh begitu juga sebaliknya. Jika biaya operasional meningkat, maka laba akan menurun.

$\mathrm{H}_{4}$ : Tingkat pertumbuhan biaya tenaga kerja berpengaruh negatif terhadap pertumbuhan laba LPD. 


\section{METODE PENELITIAN}

Penelitian ini dilakukan dengan mengambil wilayah pengujian pada LPD di Kota Denpasar sebab peranan LPD di Kota Denpasar dianggap semakin penting yang dilihat dari bertambah banyaknya jumlah LPD di Kota Denpasar dan memiliki penduduk yang cukup banyak yang sekaligus merupakan sasaran operasional LPD. Selain itu, Kota Denpasar merupakan daerah dengan tingkat perekonomian yang paling maju apabila di bandingkan dengan daerah lainnya, sehingga LPD di Kota Denpasar dinilai sebagai obyek penelitian yang paling ideal.

Variabel bebas dalam penelitian ini adalah tingkat perputaran kas $\left(\mathrm{X}_{1}\right)$, tingkat pertumbuhan kredit $\left(\mathrm{X}_{2}\right)$, tingkat pertumbuhan. tabungan $\left(\mathrm{X}_{3}\right)$, tingkat pertumbuhan biaya tenaga kerja $\left(\mathrm{X}_{4}\right)$. Variabel terikat dalam penelitian ini adalah tingkat pertumbuhan laba (Y).

Mukarromah \& Badjra, (2015) pertumbuhan laba dapat diukur dengan rumus sebagai berikut:

Pertumbuhan Laba $=\frac{\text { Total Laba }_{\mathrm{t}}-\text { Total Laba }_{\mathrm{t}-1}}{\text { Total Laba }_{\mathrm{t}-1}} \times 100 \%$

Ernian Friskayani, Made,dkk.,(2014) tingkat perputaran kas dapat diukur dengan rumus sebagai berikut:

\footnotetext{
Pendapatan Operasional .

Tingkat perputaran kas $=\quad$ Rata - Rata Kas

Kas Awal + Kas Akhir

Rata-rata kas $=$ 2

Mukarromah \& Badjra, (2015) pertumbuhan kredit diukur dengan menggunakan rumus sebagai berikut:
} 


$$
\begin{aligned}
& \text { Total Kredit }{ }_{\mathrm{t}-1} \\
& \text { Pertumbuhan kredit }=\longrightarrow \times 100 \%
\end{aligned}
$$

$$
\begin{aligned}
& \text { Pertumbuhan tabungan }=^{\text {Total } \text { Tabungan }_{\mathrm{t}}-\text { Total Tabungan }_{\mathrm{t}-1}} \mathrm{x} 100 \% \ldots \ldots(5) \\
& \text { Total Tabungan }{ }_{\mathrm{t}-1}
\end{aligned}
$$

Rumus yang digunakan untuk menghitung pertumbuhan biaya tenaga kerja. Menurut Kristiadi, dkk., (2015) yaitu sebagai berikut:

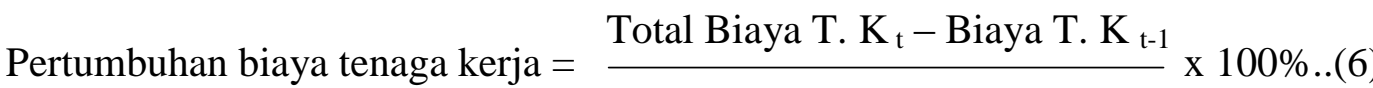
Total Biaya T. $\mathrm{K}_{\mathrm{t}-1}$

Populasi dalam penelitian ini adalah 35 LPD yang terdaftar di LPLPD Kota Denpasar Tahun 2014-2017. Metode yang digunakan dalam penentuan sampel dalam metode penelitian ini yaitu metode purposive sampling.

Analisis statistik yang digunakan adalah regresi linear berganda. Analisis regresi linear berganda dilakukan untuk mengetahui hubungan antara lebih dari dua variabel, yaitu satu variabel sebagai variabel dependen dan beberapa variabel lain sebagai variabel independen. Pengujian hipotesis ini dilakukan dengan menggunakan alat Statistical Package for Social Science (SPSS) dengan tingkat signifikan $5 \%(\alpha-0,05)$. Dalam menguji hipotesis dikembangkan suatu persamaan untuk menyatakan hubungan antar variabel dependen, yaitu Y (tingkat pertumbuhan laba) dengan variabel independen, yaitu X (tingkat perputaran kas, tingkat pertumbuhan kredit, tingkat pertumbuhan tabungan, tingkat pertumbuhan biaya tenaga kerja). Pengujian hipotesis dengan analisis regresi linear berganda diformulasikan sebagai berikut: 
$Y=\alpha+\beta 1 X_{1}+\beta 2 X_{2}+\beta 3 X_{3}+\beta 4 X_{4}+e$

Keterangan :

$\begin{array}{ll}\text { A } & \text { : Nilai Konstanta } \\ \beta 1, \beta 2, \beta 3, \beta 4, & \text { : Koefisien regresi variabel independen } \\ \text { XI } & \text { : Tingkat Perputaran Kas } \\ \text { X2 } & \text { : Tingkat Pertumbuhan Kredit } \\ \text { X3 } & \text { :Tingkat Pertumbuhan Tabungan } \\ \text { X4 } & \text { : Tingkat Pertumbuhan Biaya Tenaga Kerja } \\ \text { Y } & \text { : Pertumbuhan Laba } \\ \text { E } & : \text { Standard error }\end{array}$

Secara statistik, hal tersebut dapat dilihat dari nilai koefisien determinasi $\left(\mathrm{R}^{2}\right.$ ), nilai statistik $\mathrm{F}$ (uji signifikansi simultan), dan nilai statistik $\mathrm{t}$ (uji signifikansi parsial).

\section{HASIL DAN PEMBAHASAN}

Penyajian statistik deskriptif dilakukan untuk menginformasikan karakteristik variabel-variabel penelitian, seperti nilai terkecil, nilai terbesar, rata-rata dan standar deviasi. Hasil uji statistik deskriptif disajikan dalam Tabel 3 berikut.

Tabel 3.

Hasil Uji Statistik Deskriptif

\begin{tabular}{|c|c|c|c|c|c|}
\hline & $\mathrm{N}$ & Minimum & Maximum & Mean & Std. Deviation \\
\hline $\begin{array}{l}\text { Tingkat Perputaran } \\
\text { Kas }\end{array}$ & 136 & .44220 & 307.04851 & 18.9948376 & 38.51827094 \\
\hline Tingkat & & & & & \\
\hline $\begin{array}{l}\text { Pertumbuhan } \\
\text { Kredit }\end{array}$ & 136 & -.20349 & .91952 & .1730272 & .16393857 \\
\hline $\begin{array}{l}\text { Pertumbuhan } \\
\text { Tabungan } \\
\text { Tingkat }\end{array}$ & 136 & -.04008 & .48922 & .0230691 & .04890012 \\
\hline $\begin{array}{l}\text { Pertumbuhan } \\
\text { Biaya tenaga kerja }\end{array}$ & 136 & .00326 & 2.26143 & .1173693 & .19447402 \\
\hline Pertumbuhan Laba & 136 & -.56144 & 1.32084 & .1450738 & .22372676 \\
\hline Valid N (listwise) & 136 & & & & \\
\hline
\end{tabular}

Berdasarkan hasil statistic deskriptif yang ditunjukkan pada tabel 3 didapat hasil bahwa sampel yang berjumlah 136 dan mempunyai hasil tingkat perputaran 
kas memiliki nilai minimum 0,44220. Nilai maksimum sebesar 307,04851 dan mean sebesar 18,9948376 dengan standar deviasi sebesar 38,51827094 artinya terjadi penyimpangan nilai perputaran kas terhadap nilai rata-ratanya sebesar 38,51827094 .

Tingkat Pertumbuhan kredit memiliki nilai minimum -0,20349. Nilai maksimum sebesar 0,91952 dan mean sebesar 0,1730272 dengan standar deviasi sebesar 0,16393857 artinya terjadi penyimpangan nilai perputaran kas terhadap nilai rata-ratanya sebesar 0,16393857 .

Tingkat Pertumbuhan tabungan memiliki nilai minimum -0,04008. Nilai maksimum sebesar 0,48922 dan mean sebesar 0,0230691 dengan standar deviasi sebesar 0,04890012 artinya terjadi penyimpangan nilai perputaran kas terhadap nilai rata-ratanya sebesar 0,04890012 .

Tingkat Pertumbuhan biaya tenaga kerja memiliki nilai minimum 0,00326. Nilai maksimum sebesar 2,26143 dan mean sebesar 0,1173693 dengan standar deviasi sebesar 0,19447402 artinya terjadi penyimpangan nilai perputaran kas terhadap nilai rata-ratanya sebesar 0,19447402 .

Tingkat Pertumbuhan laba memiliki nilai minimum -0,56144. Nilai maksimum sebesar 1,32084 dan mean sebesar 0,1450738 dengan standar deviasi sebesar 0,22372676 artinya terjadi penyimpangan nilai perputaran kas terhadap nilai rata-ratanya sebesar 0,22372676 .

Dalam menguji hipotesis dikembangkan suatu persamaan untuk menyatakan hubungan antar variabel dependen, yaitu Y (tingkat pertumbuhan laba) dengan variabel independen, yaitu X (tingkat perputaran kas, tingkat pertumbuhan kredit, 
tingkat pertumbuhan tabungan, tingkat pertumbuhan biaya tenaga kerja). Hasil analisis regresi linier berganda dapat dilihat pada tabel 3.

\section{Tabel 4.}

\section{Hasil Uji Regresi Linier Berganda}

\begin{tabular}{|c|c|c|c|c|c|}
\hline Model & \multicolumn{2}{|c|}{$\begin{array}{l}\text { Unstandardized } \\
\text { Coefficients }\end{array}$} & $\begin{array}{c}\text { Standardized } \\
\text { Coefficients } \\
\text { Beta }\end{array}$ & $\mathrm{t}$ & Sig. \\
\hline (Constant) & .043 & .028 & & 1.522 & .130 \\
\hline $\begin{array}{l}\text { Tingkat Perputaran } \\
\text { Kas }\end{array}$ & .011 & .001 & .559 & 11.108 & .000 \\
\hline $\begin{array}{l}\text { Tingkat Pertumbuhan } \\
\text { Kredit }\end{array}$ & .734 & .076 & .475 & 9.625 & .000 \\
\hline $\begin{array}{l}\text { Tingkat Pertumbuhan } \\
\text { Tabungan }\end{array}$ & -4.325 & .577 & -.377 & -7.498 & .000 \\
\hline $\begin{array}{l}\text { Tingkat Pertumbuhan } \\
\text { Biaya tenaga kerja }\end{array}$ & -1.100 & .182 & -.299 & -6.047 & .000 \\
\hline
\end{tabular}

Berdasarkan Tabel 3 dapat dibuat persamaan regresi linier berganda sebagai berikut: $\mathrm{Y}=0,043+0,011 \mathrm{X}_{1}+0,734 \mathrm{X}_{2}-4,325 \mathrm{X}_{3}-1,100 \mathrm{X}_{4}+0,028$. Konstanta ( $\alpha$ ) sebesar 0,043 memiliki arti apabila tingkat perputaran kas, tingkat pertumbuhan kredit, tingkat pertumbuhan tabungan dan tingkat pertumbuhan biaya memiliki nilai konstan pada angka nol maka nilai tingkat pertumbuhan laba akan meningkat sebesar 0,043 satuan. Koefisien regresi variabel tingkat perputaran kas sebesar 0,011 memiliki arti apabila tingkat perputaran kas meningkat satu satuan maka tingkat pertumbuhan laba meningkat sebesar 0,011 satuan dengan asumsi variabel lainnya konstan. Koefisien regresi variabel tingkat pertumbuhan kredit sebesar 0,734 memiliki arti apabila perputaran kredit meningkat satu satuan maka pertumbuhan laba meningkat sebesar 0,734 satuan dengan asumsi variabel lainnya konstan. Koefisien regresi variabel tingkat pertumbuhan tabungan sebesar $-4,325$ memiliki arti apabila pertumbuhan tabungan meningkat satu satuan maka pertumbuhan laba menurun sebesar 4,325 
satuan dengan asumsi variabel lainnya konstan. Koefisien regresi variabel tingkat pertumbuhan biaya tenaga kerja sebesar -1,100 memiliki arti apabila pertumbuhan biaya tenaga kerja meningkat satu satuan maka pertumbuhan laba menurun sebesar 1,100 satuan dengan asumsi variabel lainnya konstan.

Nilai koefisien determinasi adalah antar nol sampai satu $\left(0<\mathrm{R}^{2}<1\right)$. Nilai $\mathrm{R}^{2}$ yang kecil berarti mempunyai kemampuan variabel-variabel independen dalam menjelaskan variasi dependen sangat terbatas. Nilai yang mendekati satu berarti variabel-variabel independen dapat memberikan hampir semua informasi yang dibutuhkan untuk menerangkan variabel dependen. Koefisien determinasi dapat dilihat melalui nilai adjusted $\mathrm{R}^{2}$. Hasil ujikoefisien determinasi dapat dilihat pada tabel 4.

Tabel 5.

Hasil Uji Koefisien Determinasi

\begin{tabular}{lllll}
\hline Model & $\mathrm{R}$ & $\mathrm{R}$ Square & Adjusted R Square & Std. Error of the Estimate \\
\hline 1 & $.862^{\mathrm{a}}$ & .744 & .736 & .11494053 \\
\hline Sumber: Data diolah, 2018 & & &
\end{tabular}

Berdasarkan tabel 4. dapat diamati nilai adjused $\mathrm{R}^{2}$ sebesar 0,736 berarti 73,6\% perubahan (naik turun) pada pertumbuhan laba yang dipengaruhi oleh tingkat perputaran kas, tingkat pertumbuhan tabungan, tingkat pertumbuhan kredit dan tingkat pertumbuhan biaya tenaga kerja, sementara sisanya sejumlah $26,4 \%$ dipengaruhi oleh faktor-faktor lain diluar penelitian ini.

Kriteria penilaian dilakukan dengan membandingkan nilai signifikan $F_{\text {hitung }}$ dengan nilai signifikan a. Apabila nilai signifikan $F_{\text {hitung }}$ kurang dari $=\alpha 0,05$ maka model penelitian dapat atau layak digunakan. Apabila tingkat signifikan $\mathrm{F} \leq$ $\alpha 0,05$, maka $\mathrm{H}_{\mathrm{i}}$ diterima dan $\mathrm{H}_{\mathrm{o}}$ ditolak. Namun, bila tingkat signifikan $\mathrm{F}>\alpha$ 
0,05, maka $\mathrm{H}_{\mathrm{i}}$ ditolak dan $\mathrm{H}_{\mathrm{o}}$ diterima. Hasil uji signifikan simultan $\mathrm{F}$ dapat dilihat pada tabel 5 .

Tabel 6.

Hasil Uji Signifikansi Simultan F

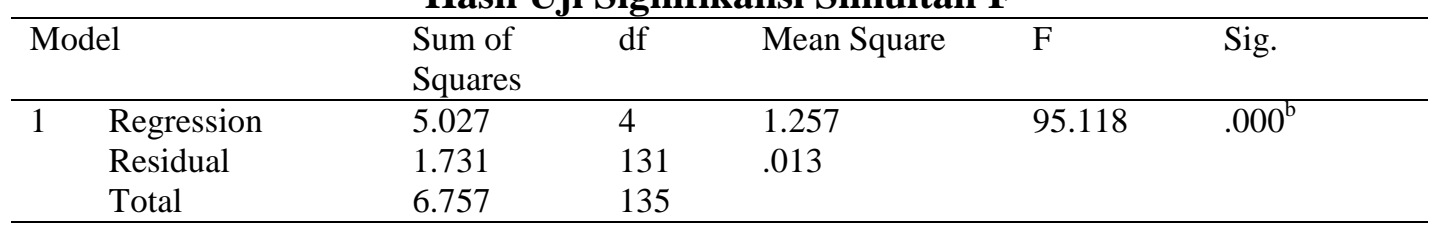

Sumber: Data diolah, 2018

Berdasarkan Tabel 5 di atas dapat dilihat nilai signifikan $\mathrm{F}$ yakni 0,000 kurang dari $0,05(0,000<0,05)$, berarti tingkat perputaran kas, tingkat pertumbuhan tabungan, tingkat pertumbuhan kredit dan tingkat pertumbuhan biaya tenaga kerja secara simultan berpengaruh terhadap pertumbuhan laba.

Kriteria penilaian dilakukan dengan melihat hasil regresi dengan program SPSS, yaitu membandingkat tingkat signifikan masing-masing variabel bebas dengan $\alpha=0,05$. Apabila tingkat signifikansi $\mathrm{t} \leq \alpha=0,05$, maka $\mathrm{H}_{1}$ diterima dan $\mathrm{H}_{2}$ ditolak. Namun bila tingkat signfikansi $\mathrm{t}>\alpha=0,05$, maka $\mathrm{H}_{1}$ ditolak dan $\mathrm{H}_{2}$ diterima. Hasil uji signifikan parsial t dapat dilihat pada tabel 6. 
Tabel 7.

Hasil Uji Signifikansi Parsial

\begin{tabular}{|c|c|c|c|c|c|}
\hline Model & \multicolumn{2}{|c|}{$\begin{array}{l}\text { Unstandardized } \\
\text { Coefficients }\end{array}$} & $\begin{array}{c}\text { Standardized } \\
\text { Coefficients } \\
\text { Beta }\end{array}$ & $\mathrm{t}$ & Sig. \\
\hline (Constant) & .043 & .028 & & 1.522 & .130 \\
\hline $\begin{array}{l}\text { Tingkat Perputaran } \\
\text { Kas }\end{array}$ & .011 & .001 & .559 & 11.108 & .000 \\
\hline $\begin{array}{l}\text { Tingkat Pertumbuhan } \\
\text { Kredit }\end{array}$ & .734 & .076 & .475 & 9.625 & .000 \\
\hline $\begin{array}{l}\text { Tingkat Pertumbuhan } \\
\text { Tabungan }\end{array}$ & -4.325 & .577 & -.377 & -7.498 & .000 \\
\hline $\begin{array}{l}\text { Tingkat Pertumbuhan } \\
\text { Biaya tenaga kerja }\end{array}$ & -1.100 & .182 & -.299 & -6.047 & .000 \\
\hline
\end{tabular}

Hasil pengujian uji signifikansi parsial (uji statistik t) dapat diuraikan sebagai berikut.

Berdasarkan tabel 6 dapat dilihat bahwa tingkat perputaran kas memiliki nilai $\beta_{1}$ sebesar 0,011 yang bernilai positif serta besar signifikansi 0,000 lebih kecil dibandingkan dengan 0,05. Artinya tingkat perputaran kas berpengaruh signifikan positif terhadap pertumbuhan laba, hal ini menunjukkan apabila terjadi peningkatan tingkat perputaran kas maka akan terjadi peningkatan pada pertumbuhan laba.

Berdasarkan tabel 6 dapat dilihat bahwa tingkat pertumbuhan kredit memiliki nilai $\beta_{2}$ sebesar 0,734 yang bernilai positif serta besar signifikansi 0,000 lebih kecil dibandingkan dengan 0,05. Artinya tingkat pertumbuhan kredit berpengaruh positif terhadap pertumbuhan laba, hal ini menunjukkan apabila terjadi peningkatan pertumbuhan kredit maka akan terjadi peningkatan pada pertumbuhan laba.

Berdasarkan tabel 6 dapat dilihat bahwa tingkat pertumbuhan tabungan memiliki nilai $\beta_{3}$ sebesar $-4,325$ yang bernilai negatif serta besar signifikansi 
0,000 lebih kecil dibandingkan dengan 0,05. Artinya tingkat pertumbuhan tabungan berpengaruh signifikan negatif terhadap pertumbuhan laba, hal ini menunjukkan apabila terjadi peningkatan pertumbuhan tabungan maka akan terjadi penurunan pada pertumbuhan laba.

Berdasarkan tabel 6 dapat dilihat bahwa tingkat pertumbuhan biaya tenaga kerja memiliki nilai $\beta_{4}$ sebesar $-1,100$ yang bernilai negatif serta besar signifikansi 0,000 lebih kecil dibandingkan dengan 0,05. Artinya tingkat pertumbuhan biaya tenaga kerja berpengaruh signifikan negatif terhadap pertumbuhan laba, hal ini menunjukkan apabila terjadi peningkatan pertumbuhan biaya tenaga kerja maka akan terjadi penurunan pada pertumbuhan laba.

Hasil uji parsial hipotesis pertama $\left(\mathrm{H}_{1}\right)$ menyatakan tingkat perputaran kas berpengaruh positif pada pertumbuhan laba LPD. Semakin tinggi tingkat perputaran kas, maka pertumbuhan laba LPD akan semakin meningkat. Hal ini menunjukan LPD mampu mengelola kasnya secara efektif dan efisien yang akan berdampak pada adanya perputaran kas LPD yang baik sehingga pertumbuhan laba akan menjadi meningkat. Tingginya tingkat perputaran kas, juga mencerminkan tingginya efisiensi penggunaan kas yang baik sehingga diharapkan akan berpengaruh positif pada pertumbuhan laba LPD di Kota Denpasar.

Hasil penelitian ini sejalan dengan penelitian yang dilakukan oleh Prawira \& Wisadha (2010), yang mengatakan bahwa apabila tingkat perputaran kas meningkat maka profitabilitas juga akan meningkat, karena dengan tingkat perputaran kas yang tinggi telah menunjukkan bahwa terjadinya volume transaksi yang tinggi, dengan tingkat pendapatan yang lebih besar akan memberikan 
kemungkinan laba yang lebih besar sepanjang biaya operasional tidak meningkat. Peningkatan laba yang diterima akan membuat tingkat profitabilitas. Hasil penelitian yang dilakukan Sutika\& Sujana (2013), yang mengatakan bahwa apabila tingkat perputaran kas meningkat, maka profitabilitas LPD di Kecamatan Ubud juga meningkat.

Hasil Uji Parsial hipotesis kedua $\left(\mathrm{H}_{2}\right)$ menyatakan tingkat pertumbuhan kredit berpengaruh positif terhadap pertumbuhan laba, hal ini menunjukkan apabila terjadi peningkatan pertumbuhan kredit maka akan terjadi peningkatan pada pertumbuhan laba. Tingginya tingkat pertumbuhan kredit mengindikasikan bahwa LPD mampu menyalurkan kredit secara baik kepada masyarakat Desa Pekraman. Hal itu menunjukkan adanya pertumbuhan laba yang tinggi pada LPD di Kota Denpasar.

Pertumbuhan kredit menggambarkan tingkat perkembangan volume kredit yang disalurkan kepada pihak ketiga mampu memberikan peningkatan profitabilitas dan meningkatkan kinerja perbankan. Dengan tingginya kredit yang disalurkan pada masyarakat akan menunjukan semakin tinggi penjualan berupa kredit sehingga keuntungan atau laba dapat secara otomatis meningkat.

Hasil penelitian ini sesuai dengan penelitian dilakukan oleh Hariputri \& Dharmadiaksa(2018)yang menunjukkan bahwavariabel tingkat pertumbuhan kredit berpengaruh positif terhadap profitabilitas Lembaga Perkreditan Desa (LPD) di Kota Denpasar periode 2014-2016. Hal ini dapat dikatakan LPD mampu menyalurkan kredit dengan cukup baik kepada masyarakat yang menyebabkan semakin banyak pendapat bunga yang diterima LPD sehinnga profitabilitas LPD 
semakin meningkat. Sastrawan, dkk. (2014) dalam penelitiannya juga menyatakan bahwa tingkat pertumbuhan kredit berpengaruh positif dan signifikan terhadap pertumbuhan profitabilitas pada Lembaga Perkreditan Desa (LPD) Desa Pakraman Banjar.

Berdasarkan hasil uji parsial hipotesis ketiga $\left(\mathrm{H}_{3}\right)$ menyatakan tingkat pertumbuhan tabungan berpengaruh negatif terhadap pertumbuhan laba. Semakin tinggi tingkat pertumbuhan tabunganmaka akan terjadi penurunan pada pertumbuhan laba. Hal ini dikarenakan pihakmanajemen LPD tidak efektif dalam melakukan perputaran dana atau asset yang dimikili LPD sehingga laba LPD cenderung menurun. Pertumbuhan tabungan yang meningkat menyebabkan banyaknya dana yang terhimpun dan mengindikasikan bahwa ada banyak dana yang tidak tersalurkan. Apabila dana LPD tidak disalurkan, maka akan terjadi penumpukan biaya bunga yang harus dibayarkan LPD sehingga pertumbuhan laba LPD pun akan cenderung menurun.

Hasil penelitian yang sesuai dengan yang dilakukan oleh (Mukarromah \& Badjra, 2015).Keadaan tersebut dapat disebabkan oleh terjadinya ketidakseimbangan dana yang dihimpun dengan dana yang disalurkan BPR. BPR memperoleh pendapatan dari kredit yang disalurkan, dimana keuntungan pendapatan tersebut dihasilkan dari selisih antara bunga dana dengan bunga kredit. Sejalan dengan penelitian yang dilakukan Kurniawan (2012), “menyatakan bahwa dana pihak ketiga secara parsial berpengaruh tidak signifikan terhadap ROA. Hal ini disebabkan karena sumber dana dapat menentukan kelancaran operasi perusahaan. Apabila dikelola secara optimal akan dapat menghasilkan 
laba yang diharapkan oleh perusahaan". Cahyani (2013), "menyatakan bahwa pertumbuhan tabungan berlawanan dengan pertumbuhan profitabilitas karena biaya bunga yang harus dibayarkan oleh pihak BPR semakin besar dan biaya operasional yang harus dikeluarkan juga semakin besar”.

Berdasarkan hasil uji parsial hipotesis keempat $\left(\mathrm{H}_{4}\right)$ menyatakan pertumbuhan biaya tenaga kerja berpengaruh negatif terhadap pertumbuhan laba, hal ini menunjukkan apabila terjadi peningkatan pertumbuhan biaya tenaga kerja maka akan terjadi penurunan pada pertumbuhan laba. Laba atau rugi dari suatu LPD didapat dari hasil pengurangan antara pendapatan operasional LPD dengan biaya operasional LPD. Biaya tenaga kerja merupakan salah satu biaya operasional yang dikeluarkan oleh LPD. Semakin tinggi biaya tenaga kerja mengindikasikan bahwa banyaknya tenaga kerja yang dimiliki oleh LPD. Biaya tenaga kerja yang tinggi maka biaya operasional LPD juga semakin tinggi sehingga cenderung menurunkan pertumbuhan laba LPD.

Hasil penelitian ini sesuai dengan penelitian yang dilakukan oleh Martha, dkk (2015), yang menyatakan bahwa biaya operasional memiliki pengaruh yang negatif terhadap laba. Artinya, semakin tinggi nilai biaya operasional maka semakin rendah laba yang diperoleh begitu juga sebaliknya. Hal tersebut juga sejalan dengan hasil penelitian yang dilakukan oleh Oki (2010) yang menyatakan terdapat pengaruh negatif dan signifikan dari biaya operasional terhadap laba. Tingkat keeratan hubungan (korelasi) sangat kuat, jika biaya operasional meningkat, maka laba akan menurun. 


\section{SIMPULAN}

Tingkat perputaran kas berpengaruh positif terhadap pertumbuhan laba. Hal ini berarti apabila tingkat perputaran kas semakin meningkat maka pertumbuhan laba semakin meningkat pula.

Tingkat pertumbuhan kredit berpengaruh positif terhadap pertumbuhan laba. Hal ini berarti apabila pertumbuhan kredit semakin meningkat maka pertumbuhan laba semakin meningkat pula.

Tingkat pertumbuhan tabungan berpengaruh negatif terhadap pertumbuhan laba. Hal ini berarti apabila pertumbuhan tabungan semakin meningkat maka pertumbuhan laba semakin menurun.

Pertumbuhan biaya tenaga kerja berpengaruh negatif terhadap pertumbuhan laba. Hal ini berarti apabila pertumbuhan biaya tenaga kerja semakin meningkat maka pertumbuhan laba semakin menurun.

Bagi peneliti selanjutnya, disarankan untuk menambah variabel lain yang dapat menunjukkan serta menjelaskan adanya pertumbuhan laba yang lebih baik didalam suatu LPD serta dapat menggunakan tahun pengamatan yang berbeda agar dapat melihat lebih jelas mengenai variabel yang memengaruhi LPD dalam meningkatkan labanya.

Bagi LPD yang berada di Kota Denpasar diharapkan untuk membuat kebijakan keuangan yang lebih baik serta mampu mengelola laba dengan lebih optimal agar pertumbuhan laba LPD menjadi lebih meningkat. 


\section{REFERENSI}

Abdurrahman Antoni and Muhammad Nasri. (2015). Profitability Determinants of Go - Public Bank in Indonesia: Empirical Evidence after Global Finance Crisis. International Journal of Bussiness and Management Invention, 4 (1) pp: $37-46$.

Athanasoglou, P.P., Brissimis. S.N ., and Delis, M.D. (2008). Bank-Speecific. Industry-Specific and Macroeconomic Determinants of Bank Profitability. Journal of International Financial Markets, Institutional, \& Money, 18 (2), pp: 121-136.

Arta, I. W. J., \& Kesuma, I. K. W. (2012). Kredit Dan Pertumbuhan Kredit Terhadap Profitabilitas Lembaga Perkreditan Desa ( Lpd ) Di Kecamatan Tegallalang, Gianyar Fakultas Ekonomi dan Bisnis Universitas Udayana(Unud), Bali, Indonesia Fakultas Ekonomi dan Bisnis Universitas Udayana (Unud), 956-974.

Bank Indonesia. (1998). UU No.10 tahun 1998, Tentang Perubahan Terhadap UU No. 7 tahun 1992, Jakarta

Bratland, Jhon. (2010). Capital Comcepts as Insights into the Maintenance and Neglect of Infratructure. The Independent Review. Oakland.15 (1):h:36

Cahyadi, S. P. \& Mustanda, I. K. (2014). Pengaruh Cash Turnover, Loan to Deposit Ratio, Capital Adequacy Ratio, dan Dana Pihak Ketiga terhadap Profitabilitas LPD. Jurnal Manajemen, Strategi Bisnis dan Kewirausahaan Fakultas Ekonomi Universitas Udayana, 8 (2).

Cahyani, N. P. D. P., \& Dana, I. M. (2014). Pengaruh Petumbuhan Aktiva Produktif, Dana Pihak Ketiga, Dan Ukuran Perusahaan Terhadap Profitabilitas Lembaga Perkreditan Desa Di Kabupaten Badung Fakultas Ekonomi dan Bisnis Universitas Udayana ( Unud ), Bali, Indonesia Fakultas Ekonomi dan Bisnis Unud, 1050-1065

Dhanya Jagadeesh. (2015). The Impact of Savings ini Economic Growth: An Empirical Study Based on Botswana. International Journal of Research in Business Studies and Management Baisago University, 2 (9), pp: 1021.

Dewi, N. M. J. L., \& Suartana, I. W. (2017). Faktor-Faktor Yang Mempengaruhi Pertumbuhan Laba Kabupaten Gianyar Ni Made Jeny Lestari Dewi 1 Fakultas Ekonomi dan Bisnis Universitas Udayana ( Unud ), Bali , Indonesia Fakultas Ekonomi dan Bisnis Universitas Udayana ( Unud ), Bali , Indonesia ABSTRAK Le, 19, 565-592. 
Dewi, A. A. A. T., \& Budiartha, I. K. (2017). E-Jurnal Akuntansi Universitas Udayana PROFITABILITAS Anak Agung Ayu Trisna Dewi 1 Fakultas Ekonomi dan Bisnis Universitas Udayana ( Unud ), Bali , Indonesia Fakultas Ekonomi dan Bisnis Universitas Udayana ( Unud ), Bali , Indonesia ABSTRAK Ekonomi merupa, 19, 2090-2117.

Ernia. F. M, Ananta, W. \& Lucy, S. M. (2014). Pengaruh Tingkat Perputaran Kas, Perputaran Kredit, Biaya Operasional Pendapatan Operasional (BOPO), Kecukupan Modal dan Jumlah Nasabah terhadap Profitabilitas. E-Journal S1 Akuntansi Universitas Pendidikan Ganesha, 2 (1).

Finger,C. A., (1994). The Ability of Earnings to Predict Future Earnings and Cash Flow, Journal of Accounting Research, Vol. 32 , No. 2 Autumn, p. 210223.

Idowu., A.\& Awoyemi., S. O. (2014). The Impact of Credit Risk Management on the Commercial Banks Performance in Nigeria. International Journal of Management and Sustainability, 3 (5), pp: 295-306.

Kasmir. (2014). Analisis Laporan Keuangan. Edisi satu. Cetakan Ketujuh. Jakarta: PT. Raja Grafindo Persada.

Martha, I. M. K., Bagia, I. W., \& Suwendra, I. W. (2015). Pengaruh Kredit yang Disalurkan dan Biaya Operasional Terhadap Laba Lembaga Prekreditan Desa (LPD). E-Journal Bisma Universitas Pendidikan Ganesha, 3(1), 1-9.

Menuh, Ni Nyoman. (2008). Pengaruh Efektifitas dan Efisiensi Penggunaan Modal Kerja terhadap Rentabilitas Ekonomis pada Koperasi Kamadhuk RSUP Sanglah Denpasar. Jurnal Forum Manajemen, 6 (I), pp: 89- 96.

Mukarromah, L., \& Badjra, I. B. (2015). Pengaruh pertumbuhan tabungan, deposito, dan kredit terhadap pertumbuhan profitabilitas pt bpr partakencana tohpati denpasar, 4(8), 2286-2300.

Oki. (2010). Pengaruh Biaya Operasional terhadap laba PT. PINDAD (Persero) Bandung.

Peraturan Daerah Provinsi Bali Nomor 3 Tahun 2017 tentang Lembaga Perkreditan Desa sebagai mana telah diubah beberapa kali terakhir dengan peraturan daerah provinsi Bali Nomor 4 tahun 2012 tentang perubahan kedua atas peraturan daerah provinsi Bali nomor 3 Tahun 2017 tentang perkreditan desa.

Pratama, Septian. A., \& Putri, I. G. A. M. Asri Dwija. (2013). Profitabilitas BPR Di Kota Denpasar I Wayan Septian Aditya Pratama 1 Fakultas Ekonomi dan Bisnis Universitas Udayana, Bali , Indonesia Fakultas Ekonomi dan 
Bisnis Universitas Udayana, Bali , Indonesia, Vol. 2, 436-450.

Prawira, I. W. A. B., \& Wisadha, I. G. S. (2010). Pengaruh Tingkat Perputaran Kas, Pertumbuhan Kredit, Dan Rasio Bopo Pada Profitabilitas Lpd Di Kota Denpasar Periode 2006-2010. Universitas Udayana, 1-19.

Pudja, A. D., \& Suartana, I. W. (2014). Pengaruh Perputaran Kredit, Kecukupan Modal, dan Jumlah Nasabah Pada Profitabilitas Lembaga Perkreditan Desa (LPD) di Kabupaten Badung Periode 2010-2012 Ayu Dwikayanthi Pudja 1 Fakultas Ekonomi dan Bisnis Universitas Udayana ( Unud ), Bali , Indonesia Fakultas Ekonomi dan Bisnis Universitas Udayana ( Unud ), Bali , Indonesia ABSTRAK Pe, 8, 584-597.

Sastrawan, C., dan Fridayana Y. (2014). Pengaruh Pertumbuhan Tabungan dan Kredit Terhadap Profitabilitas pada Lembaga Perkreditan Desa. E-Jurnal Manajemen Bisma Universitas Pendidikan Ganesha Jurusan Manajemen, Vo.2.

Seng Sothan. (2014). Causal Relationship Between Domestic Saving and Economic Growth: Evidence from Cambodia. International Journal of Economic and Finance, 6 (9), pp:1916-9728.

Suartana, I Wayan. (2009). Arsitektur Pengelolaan Resiko Pada Lembaga Perkreditan Desa (LPD). Denpasar: Udayana University Press.

Sutika, I. K., \& Sujana, I. K. (2013). Analisis Faktor Kinerja Yang Mempengaruhi Profitabilitas Pada Lembaga Perkreditan Desa. E-Jurnal Akuntansi Universitas Udayana, 1, 68-84. 